\title{
The relationship between strategic thinking and leadership effectiveness in Kenyan indigenous banks
}

\begin{tabular}{|c|c|}
\hline \multicolumn{2}{|c|}{$\begin{array}{l}\text { Authors: } \\
\text { Samuel M. Muriithi }{ }^{1} \\
\text { Lynette Louw }{ }^{2} \\
\text { Sarah E. Radloff }\end{array}$} \\
\hline \multicolumn{2}{|c|}{$\begin{array}{l}\text { Affiliations: } \\
\text { }{ }^{1} \text { Department of Commerce, } \\
\text { School of Business and } \\
\text { Economics, Daystar } \\
\text { University, Kenya }\end{array}$} \\
\hline \multicolumn{2}{|c|}{$\begin{array}{l}\text { 2Department of } \\
\text { Management, Rhodes } \\
\text { University, South Africa }\end{array}$} \\
\hline \multicolumn{2}{|c|}{$\begin{array}{l}{ }^{3} \text { Department of Statistics, } \\
\text { Rhodes University, } \\
\text { South Africa }\end{array}$} \\
\hline \multicolumn{2}{|c|}{$\begin{array}{l}\text { Corresponding author: } \\
\text { Samuel Muriithi, } \\
\text { smuriithi@daystar.ac.ke }\end{array}$} \\
\hline \multicolumn{2}{|c|}{$\begin{array}{l}\text { Received: } 05 \text { Jan. } 2017 \\
\text { Accepted: } 22 \text { Jan. } 2018 \\
\text { Published: } 19 \text { Apr. } 2018\end{array}$} \\
\hline \multicolumn{2}{|c|}{$\begin{array}{l}\text { How to cite this article: } \\
\text { Muriithi, S.M., Louw, L. \& } \\
\text { Radloff, S.E., 2018, 'The } \\
\text { relationship between } \\
\text { strategic thinking and } \\
\text { leadership effectiveness in } \\
\text { Kenyan indigenous banks', } \\
\text { South African Journal of } \\
\text { Economic and Management } \\
\text { Sciences 21(1), a1741. } \\
\text { https://doi.org/10.4102/ } \\
\text { sajems.v21i1.1741 }\end{array}$} \\
\hline \multicolumn{2}{|c|}{$\begin{array}{l}\text { Copyright: } \\
\text { ( 2018. The Authors. } \\
\text { Licensee: AOSIS. This work } \\
\text { is licensed under the } \\
\text { Creative Commons } \\
\text { Attribution License. }\end{array}$} \\
\hline \multicolumn{2}{|l|}{ Read onlin } \\
\hline 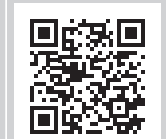 & $\begin{array}{l}\text { Scan this QR } \\
\text { code with your } \\
\text { smart phone or } \\
\text { mobile device } \\
\text { to read online. }\end{array}$ \\
\hline
\end{tabular}

Background: Leadership effectiveness is critical to organisational performance and survival. To be effective, organisational leaders must possess the right competencies. One vital leadership competency is strategic thinking, which is described as the ability to synthesise and utilise intuition and creativity in order for an organisation to achieve an integrated perspective. Strategic thinking remains a critical area for research, owing to lack of supporting empirical literature, and to theories that give little or no guidance to leaders.

Aim: The purpose of this study is to empirically test the relationship between strategic thinking competency and leadership effectiveness in Kenyan indigenous banks.

Setting: The setting of the study is the indigenous banks in Kenya.

Methods: The study was based on a positivist research paradigm which is quantitative in nature and utilised a survey method to collect data. Both probability and non-probability methods were used to determine the target population. The research instrument was a selfadministered, closed-ended questionnaire. From a target population of 494 individuals, a total of 257 responses were received and analysed. The analysis was performed using structural equation modelling with confirmatory factor analysis, Cronbach's alpha and goodness-of-fit indices being used for analysis and testing relationships.

Results: The overall findings are that a positive relationship exists between strategic thinking and leadership effectiveness in indigenous banks in Kenya. The study further establishes positive relationships between the strategic thinking competency and its sub-constructs of general strategic thinking, intent-focused and hypothesis-driven, but a negative relationship with intelligent opportunism. A similar positive relationship exists between leadership effectiveness and its sub-constructs of influence, follower commitment and versatility.

Conclusion: This research has established that strategic thinking is an important determinant of leadership effectiveness for indigenous banks in Kenya, and therefore supports prevailing literature and theory indicating a positive relationship. The implication of the study is that bank management should strive to maintain strategic thinking competency for effective leadership, successful bank performance and stability.

\section{Introduction}

The banking industry remains one of the greatest agencies of commerce in the contemporary world (EY 2015). In spite of its positive contribution to commerce, however, the banking industry is blamed for many economic upheavals and financial crises worldwide (Brunnermerier 2009). For several decades, banking behaviour and practices have been associated with crises leading to dismal performances of most world economies, both developed and developing (Grant Thornton 2013).

On the African continent, the bank industry is characterised by small-sized banks, unstable markets, poor economies, low deposits and a dominance of foreign banks (Van Ballekom 2013). Compared with other world economies, Africa remains the smallest player and contributor in the financial sense (Mlachila, Park \& Yaraba 2013). The continent has also experienced numerous financial crises over the last five decades associated with poor management and poor leadership (Ambutsi 2005; Mwangi 2012; Njuguna 2013; Sokpor 2006). These financial crises have not spared countries such as Kenya, which experienced dismal performance in its financial sector from 1970 to 2005. During this period, more than 20 banks closed down or became bankrupt (Ambutsi 2005; Mwangi 2012; Sokpor 2006). 
For banks to be successful, leadership effectiveness is critical (Grant Thornton 2013; Kubicek 2011). Such leadership can only be realised if bank leaders possess the right competencies to perform the required tasks effectively (Al-Zoubi 2012; Mintzberg 1994). One vital leadership skill that is essential for organisational effectiveness is strategic thinking. Different models developed by scholars such as Amos (2012), Barnes (2013) and Schoonover (2011) have singled out strategic thinking as a major ability associated with leadership effectiveness. According to Hogan, Hogan and Kaiser (2009), strategic thinking is the ability to plan, organise, coordinate, monitor and make use of available resources. Chilcoat (1995) comments that effective leaders demonstrate more strategic thinking competency than ineffective leaders do, whether in the banking industry or in other situations. This point is supported by Fairholm (2009:12) who argues that strategic thinking competency enables organisations to change and adapt to future challenges. Goldman (2012) emphasises that leaders who think strategically are good decision-makers and contribute greater value to their organisations. Personnel Decisions International Corporation (2001) further observes that strategic thinking competency is considered a major component of leadership requirements in the contemporary volatile environment.

Given the importance of strategic thinking as a leadership competency and the lack of research on strategic thinking competency focusing on Kenyan banking leadership, this study aims to investigate the relationship between strategic thinking competency and leadership effectiveness in the indigenous banking industry in Kenya. Although there is some evidence in other industries that leadership effectiveness, in turn, impacts on organisational effectiveness (Amos 2012; Bonn 2001; Fairholm 2009; Goldman 2012), those findings are not relevant to the current study.

Firstly, a brief overview of the literature on strategic thinking and leadership effectiveness is given. This is followed by a discussion of the problem statement, purpose, objectives and hypotheses. The research methodology used in this study is then described, after which the study findings are presented. To conclude, the limitations and managerial implications of the study are provided.

\section{Conceptualising strategic thinking competency}

The concept of strategic thinking competency has been debated by scholars and practitioners for the last 25 years in an effort to understand its meaning and impact on organisational leadership and performance. Although the concept is gaining interest, it is still an area considered to be under-researched (Jelenc 2008:6) as there is a lack of supporting empirical literature to clarify the role of strategic thinking in leadership effectiveness (Liedtka \& Rosenblum 1998; Rosche 2003). This has resulted in a lack of theoretical understanding, leaving little guidance for leaders (Liedtka 1998). Fairholm and Fairholm (2009:2) conceptualise strategic thinking competency as a work in progress in the world of academic literature. The mere lack of a common definition for strategic thinking has led to the concept being considered indecisive (Bonn 2001; Goldman 2007) and even being confused and interchangeably used with other leadership and management concepts such as strategy, strategic planning and strategic management (Bonn 2001; Jelenc 2008; Liedtka 1998). Mintzberg (1994:110) states that 'many practitioners and theorists have wrongly assumed that strategic planning, strategic thinking, and strategy-making are all synonymous'. However, recent studies have refined the existing literature on strategic thinking, thereby distinguishing it from the other strategy types (Goldman 2012; Haycock, Cheadle \& Bluestone 2012; Markides 2012). This reworking of the definition of strategic thinking is triggered by the popularity of and attention to this concept as being critical to leadership effectiveness (Markides 2012). Similarly, the uncertainty, complexity and turbulence of the contemporary world of business has demanded that organisational leaders and managers think strategically in order to ensure survival of their businesses (Haycock et al. 2012; Liedtka 1998).

Among the numerous definitions given by scholars, O'Shannassy (2006:14) defines strategic thinking as 'a particular way of solving strategic problems and opportunities at the individual and institutional level combining generative and rational thought processes'. Mintzberg (1994) and Raimond (1996) on the other hand see strategic thinking as the ability to synthesise and utilise intuition and creativity in order to give an integrated perspective to an organisation. Jelenc (2008) and Torset (2001) understand strategic thinking as a self-reflection on an organisation's future that must be conceived as an organisational cognitive process which is performed and supported by a group through interaction and interdependence. For the purpose of this study, strategic thinking is defined as a mental process which involves synthesising, utilising intuition and creativity to identify and solve problems. The process is meant to improve organisational performance through innovative and creative activities that enhance overall leadership effectiveness (Goldman 2012).

In order to further examine and understand strategic thinking in this study, and based on previous research by Liedtka (1998) and Jelenc (2008), it was conceptualised and analysed in terms of six sub-variables, namely strategic thinking (general), thinking in time, intent-focused, intelligent opportunism, system perspective and hypothesis-driven. The definitions of the six sub-variables investigated in this study and their corresponding measures are indicated in Table 1.

\section{Contextualising leadership effectiveness}

In the contemporary world, effectiveness is defined as the ability to achieve set targets or objectives (Yukl 1994, 2010). In terms of leadership, effectiveness implies the leaders' ability to perform and successfully attain organisational set standards (Green 2010; Yukl 2010). However, over the years, 
TABLE 1: The sub-variables of strategic thinking competency.

\begin{tabular}{|c|c|c|}
\hline Sub-variable & Definition & Measuring items \\
\hline $\begin{array}{l}\text { Strategic } \\
\text { thinking general }\end{array}$ & $\begin{array}{l}\text { Ability of leaders to comprehend } \\
\text { issues facing them in their } \\
\text { leadership tasks in relation to their } \\
\text { organisational current and future } \\
\text { performance. }\end{array}$ & $\begin{array}{l}\text { - Mistakes } \\
\text { - Solutions } \\
\text { - Encouragement } \\
\text { - Planning }\end{array}$ \\
\hline Thinking in time & $\begin{array}{l}\text { This denotes the ability to assess } \\
\text { the past and the present in order } \\
\text { to determine the future to pursue. } \\
\text { It is using the information available } \\
\text { to establish existing gaps and how } \\
\text { to address them. }\end{array}$ & $\begin{array}{l}\text { - Leadership } \\
\text { - Operations } \\
\text { - Mistakes } \\
\text { - Survival } \\
\text { - Employees } \\
\text { - Performance } \\
\text { - Political powers }\end{array}$ \\
\hline Intent-focused & $\begin{array}{l}\text { Intent-focused implies attaining a } \\
\text { particular position or point of view } \\
\text { in the long-term performance of an } \\
\text { organisation. }\end{array}$ & $\begin{array}{l}\text { - Competition } \\
\text { - Optimism } \\
\text { - Leadership } \\
\text { - Technical process } \\
\text { - Problems } \\
\text { - Culture }\end{array}$ \\
\hline $\begin{array}{l}\text { System } \\
\text { perspective }\end{array}$ & $\begin{array}{l}\text { This denotes a mental model of an } \\
\text { organisational system with a } \\
\text { proper understanding of the } \\
\text { interaction and interdependence of } \\
\text { various elements. }\end{array}$ & $\begin{array}{l}\text { - Strategic orientation } \\
\text { - Business strategy } \\
\text { - Planning }\end{array}$ \\
\hline $\begin{array}{l}\text { Intelligent } \\
\text { opportunism }\end{array}$ & $\begin{array}{l}\text { This refers to the leadership's } \\
\text { ability to focus on its effort rather } \\
\text { than on the organisation, and } \\
\text { ensure that contradictory or } \\
\text { limited information does not affect } \\
\text { making the right decisions. }\end{array}$ & $\begin{array}{l}\text { - Disputes } \\
\text { - Changes } \\
\text { - Decision-making } \\
\text { - Groups } \\
\text { - Equilibrium }\end{array}$ \\
\hline $\begin{array}{l}\text { Hypothesis- } \\
\text { driven }\end{array}$ & $\begin{array}{l}\text { This denotes the leadership's } \\
\text { ability to adjust their organisation's } \\
\text { to respond to environmental } \\
\text { challenges. }\end{array}$ & $\begin{array}{l}\text { - Environment } \\
\text { - Product } \\
\text { - Challenges } \\
\text { - Innovations } \\
\text { - Changes }\end{array}$ \\
\hline
\end{tabular}

Source: Based on Liedtka (1998) and Jelenc (2008). Please see the full reference list of the article, Muriithi, S.M., Louw, L. \& Radloff, S.E., 2018, 'The relationship between strategic
thinking and leadership effectiveness in Kenyan indigenous banks', South African Journal of thinking and leadership effectiveness in Kenyan indigenous banks', South African Journal of
Economic and Management Sciences 21(1), a1741. https://doi.org/10.4102/sajems. Economic and Management $S$ Sier
v21i1.1741, for more information

measuring effectiveness has remained a controversial subject to both scholars and practitioners owing to different measures which depend on organisations and circumstances. This has similarly affected the measurement of leadership effectiveness which still lacks a universally accepted approach (Arnold, Cooper \& Robertson 1998). Stogdill (1974) and later Bass (1990) catalogued and interpreted over 5000 studies on leadership effectiveness in an attempt to identify major similarities and differences. Burns (1978:2) further observes that leadership effectiveness 'is one of the most observed and least understood phenomena on earth'. Some of the definitions of leadership effectiveness are:

- The process of influencing other people's behaviour in order to accomplish set goals (Norma 1997).

- The ability to achieve set objectives, subordinates' attitude towards the leadership and the leadership's overall influence on the group's performance (Yukl 1994).

- The ability to successfully exercise personal inspirations and abilities resulting in attaining set organisational goals and objectives (Cooper, Fenimore \& Nirenberg 2012:1).

In the current study, leadership effectiveness is seen as the leader's influence and ability to successfully exercise personal influence on others, thereby resulting in the attainment of set goals and objectives. According to numerous studies, leadership effectiveness is measured using five main subvariables of cross-cultural competency, influence, follower commitment, versatility and group organisation (Cooper et al. 2012; Green 2010; National Centre For Research In Vocation Education [NCRVE] 1994). The definitions of the five sub-
TABLE 2: The sub-variables of leadership effectiveness.

\begin{tabular}{|c|c|c|}
\hline Sub-variable & Definition & Measuring items \\
\hline $\begin{array}{l}\text { Cross-cultural } \\
\text { competency }\end{array}$ & $\begin{array}{l}\text { The ability of leaders to } \\
\text { work with and obtain } \\
\text { results from people from } \\
\text { different cultures. }\end{array}$ & $\begin{array}{l}\text { - Cultural problems } \\
\text { - Respect } \\
\text { - Ethnicity } \\
\text { - Equality } \\
\text { - Multicultural teams }\end{array}$ \\
\hline Influence & $\begin{array}{l}\text { This is leaders' ability to } \\
\text { affect others. }\end{array}$ & $\begin{array}{l}\text { - Opportunistic } \\
\text { - Convincing } \\
\text { - Self-sacrifice } \\
\text { - Decisiveness } \\
\text { - Status quo }\end{array}$ \\
\hline Follower commitment & $\begin{array}{l}\text { Denotes group members' } \\
\text { commitment and } \\
\text { dedication to the group's } \\
\text { goals and objectives. }\end{array}$ & $\begin{array}{l}\text { - Group success } \\
\text { - Feedback } \\
\text { - Support system } \\
\text { - Focus-driven } \\
\text { - Contribution }\end{array}$ \\
\hline Versatility & $\begin{array}{l}\text { This is leaders' ability to } \\
\text { work with and obtain } \\
\text { results from others across } \\
\text { the organisation. }\end{array}$ & $\begin{array}{l}\text { - Multitasking } \\
\text { - Leadership } \\
\text { - Appropriate structures } \\
\text { - Expertise }\end{array}$ \\
\hline Group organisation & $\begin{array}{l}\text { Leaders and members work } \\
\text { together in an efficient and } \\
\text { effective way to attain } \\
\text { positive productivity. }\end{array}$ & $\begin{array}{l}\text { - Task-balancing } \\
\text { - Corrective action } \\
\text { - Understand group roles } \\
\text { - Performance review } \\
\text { - Resource management }\end{array}$ \\
\hline
\end{tabular}

Note: Adapted and modified from different scholars such as Cooper et al. (2012) and Green, (2010). Please see the full reference list of the article, Muriithi, S.M., Louw, L. \& Radloff, S.E., 2018, 'The relationship between strategic thinking and leadership effectiveness in Kenyan indigenous banks', South African Journal of Economic and Management Sciences 21(1), a1741. https://doi.org/10.4102/sajems.v21i1.1741, for more information.

variables and their corresponding measures are shown in Table 2.

\section{Problem statement}

As mentioned in the introduction to this study, for more than four decades, the Kenyan banking industry experienced poor performance (Ambutsi 2005; Mwangi 2012; Njuguna 2013; Sokpor 2006). This was attributed to credit problems, operational risks, poor management and poor leadership competencies, poor legal frameworks and weak control mechanisms, leading to insolvencies and the closure of many banks. An examination of the industry performance shows that a total of 24 financial institutions were liquidated while many were put under receivership. It is however notable that from 2003, many local banks started to institute changes meant to transform the sector - which resulted in positive performance (Central Bank of Kenya 2010).

It is clear that leadership and management skills are enhanced by having the right competencies (Goleman 1998). One critical ability necessary to attain leadership effectiveness is strategic thinking (Liedtka 1998). According to Mintzberg (1994), effective leaders are strategic thinkers. In fact, a lack of strategic thinking competency has been associated with top executives' failures and ineffectiveness worldwide (Bonn 2001; Chilcoat 1995; Haycock et al. 2012). Strategic thinking has also been associated with successful organisations in enabling them to respond to environmental challenges and adapt to future demands (Fairholm 2009:12). As such, strategic thinking is a very important skill associated with effective leaders.

Although numerous studies have been done on the Kenyan banking industry (Ambutsi 2005; Mwangi 2012; Njuguna 2013; Sokpor 2006), there is no study focusing on strategic 
thinking competency and leadership effectiveness. Specifically, the impact of strategic thinking on leadership and its effect on the overall performance of indigenous banks has never been tested empirically in this industry. Although the indigenous banks performed poorly for decades, as indicated above, they have performed better since 2005 . Because bank performance is associated with effective leaders who must possess the right competencies, this study aims to establish whether the improved performance is partially attributable to strategic thinking competency among the leaders.

\section{Research objectives}

The study investigates the relationship between strategic thinking competency (independent variable) and leadership effectiveness (dependent variable) in the Kenyan indigenous banking industry. The main objective of this study is to determine whether strategic thinking competency is positively correlated with leadership effectiveness leading to improved performance of the overall banking industry. The secondary objectives of this study are:

- To determine whether there is a positive correlation between strategic thinking competency and its subvariables, namely strategic thinking (general), thinking in time, intent-focused, intelligent opportunism, system perspective and hypothesis-driven.

- To determine whether there is a positive correlation between leadership effectiveness and its sub-variables, namely cross-cultural competency, influence, follower commitment, versatility and group organisation.

By investigating the relationship, it is believed that the findings will add value to the understanding of bank leadership effectiveness, which will in turn enhance bank performance. The hypothesised relationship results in the development of a theoretical framework and relationship as depicted in Figure 1.

The following hypothesis and sub-hypotheses were formulated and tested in order to establish whether there is a positive relationship between strategic thinking and leadership effectiveness.

\section{Main hypothesis}

$\mathbf{H}^{1}$ : There is a positive relationship between strategic thinking competency and leadership effectiveness

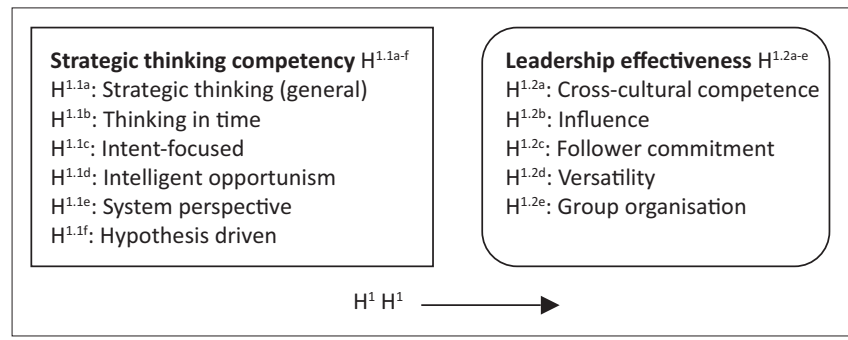

FIGURE 1: Proposed hypothesised framework of the relationship between strategic thinking competency and leadership effectiveness.
Sub-hypotheses $\mathrm{H}^{1.1}$

$\mathbf{H}^{1.1}$ : There is a relationship between the strategic thinking variable and its sub-variables:

$$
\begin{aligned}
& \mathbf{H}^{1.1 a} \text { : Strategic thinking (general) } \\
& \mathbf{H}^{1.1 b} \text { : Thinking in time } \\
& \mathbf{H}^{1.1 \mathrm{c}} \text { : Intent-focused } \\
& \mathbf{H}^{1.1 \mathrm{a}} \text { : Intelligent opportunism } \\
& \mathbf{H}^{1.11} \text { : System perspective } \\
& \mathbf{H}^{1.11} \text { : Hypothesis-driven }
\end{aligned}
$$

\section{Sub-hypotheses $\mathrm{H}^{1.2}$}

$\mathbf{H}^{1.2}$ : There is a relationship between the leadership effectiveness variable and its sub-variables:

$$
\begin{aligned}
& \mathbf{H}^{1.2 a} \text { : Cross-cultural competency } \\
& \mathbf{H}^{1.2 \mathrm{~b}} \text { : Influence } \\
& \mathbf{H}^{1.2 \mathrm{c}} \text { : Follower commitment } \\
& \mathbf{H}^{1.2 \mathrm{~d}} \text { : Versatility } \\
& \mathbf{H}^{1.2 \mathrm{e}} \text { : Group organisation }
\end{aligned}
$$

\section{Research design and methodology}

The current study used a positivist paradigm to establish the relationship between strategic thinking and leadership effectiveness, considering the quantitative nature of the data gathered by means of a survey method.

The population for this study consisted of 30 Kenyan indigenous banks and their employees. The participating banks were ranked in terms of their market share, ranging from the smallest to the largest market shares. From this ranking, the top $15(50 \%)$ of 30 indigenous banks were included in this study. However, only 13 banks finally participated in the study. A total of 494 respondents were targeted, from whom 273 questionnaires were returned, with only 257 of them being usable for statistical analysis, giving a response rate of $55.3 \%$. According to literature, 257 usable questionnaires was considered adequate for analysis in this case, since it was within the structural equation modelling (SEM) acceptable range of between 200 and 400 responses (Farrington 2009). There are also scholars who support samples of between 100 and 200 cases (Hair et al. 1998).

\section{Measuring instrument development}

In order to collect data, a survey method using a selfadministered questionnaire consisting of a cover letter and four sections was used. Section 1 of the questionnaire consisted of 20 statements and gathered information pertaining to the Kenyan indigenous banks' existence, development, leadership and performance. Section 2 covered strategic thinking competency, assessed using 38 statements, while section 3 focused on leadership effectiveness. Statements in sections 2 and 3 were measured using a multi-item labelled five-point Likert-type scale and respondents were required to indicate their level of agreement with listed items 
(where 1 = strongly disagree and $5=$ strongly agree). Finally, section 4 concentrated on demographic information of the respondents such as gender, age, education level, work position and bank rating.

The operationalisation of the independent variable, strategic thinking, and the dependent variable, leadership effectiveness, the main sources and number of items for each sub-variable are provided in Table 3.

\section{Data collection}

The distributed questionnaire was accompanied by a covering letter explaining the purpose of research, the importance of confidentiality and the need for participants' consent before participating in the research. Through the use of research assistants, some of the questionnaires were physically distributed and collected, while others were administered and completed electronically, as preferred by some respondents. The actual data collection took place over a period of 4 months.

\section{Data analysis}

The analysis of the data was performed using SEM. The software programme AMOS (IBM SPSS Statistics, Version 21, 2013) was used for the SEM. The analysis included confirmatory factor analysis (CFA) and Cronbach's alpha (CA) to assess the discriminant validity and reliability of the measuring instrument as well as the goodness-of-fit indices.

\section{Ethical consideration}

To collect the required data, the researcher obtained necessary permissions and approvals. The process of data collection was twofold: firstly a permit was obtained from the National Council for Science and Technology, a government body responsible for research conducted in Kenya. Secondly, the Department of Management at Rhodes University granted permission for the research to be conducted after meeting the required university research ethical standards. The necessary permission from targeted indigenous banks was also received.

TABLE 3: Operationalisation of the independent and dependent variables.

\begin{tabular}{|c|c|c|c|c|}
\hline Operationalisation & Sub-variable & Operationalisation of independent sub-variables & Source of definitions & Measuring items \\
\hline \multirow[t]{6}{*}{$\begin{array}{l}\text { Independent variable: } \\
\text { Strategic thinking } \\
\text { competency }\end{array}$} & $\begin{array}{l}\text { Strategic thinking } \\
\text { (general) }\end{array}$ & $\begin{array}{l}\text { Ability of leaders to comprehend issues facing } \\
\text { them in their leadership tasks in relation to their } \\
\text { organisational current and future performance. }\end{array}$ & $\begin{array}{l}\text { - Jelenc (2008) } \\
\text { - Liedtka (1998) }\end{array}$ & $\begin{array}{l}\text { - Mistakes } \\
\text { - Solutions } \\
\text { - Encouragement } \\
\text { - Planning }\end{array}$ \\
\hline & Thinking in time & $\begin{array}{l}\text { This denotes the leadership's ability to connect the } \\
\text { past, present and future in their decision-making. }\end{array}$ & $\begin{array}{l}\text { - Liedtka (1998) } \\
\text { - Liedtka and Rosenblum (1998) }\end{array}$ & $\begin{array}{l}\text { - Strategic orientation } \\
\text { - Business strategy } \\
\text { - Planning }\end{array}$ \\
\hline & Intent-focused & $\begin{array}{l}\text { This refers to the leadership's ability to position } \\
\text { the organisation for long-term performance. }\end{array}$ & $\begin{array}{l}\text { - Jelenc (2008) } \\
\text { - Liedtka and Rosenblum (1998) }\end{array}$ & $\begin{array}{l}\text { - Disputes } \\
\text { - Changes } \\
\text { - Decision-making } \\
\text { - Groups } \\
\text { - Equilibrium }\end{array}$ \\
\hline & $\begin{array}{l}\text { Intelligent } \\
\text { opportunism }\end{array}$ & $\begin{array}{l}\text { This refers to leadership's ability to concentrate its } \\
\text { effort on itself rather than the organisation, make } \\
\text { decisions based on limited information, ensure } \\
\text { that contradictory information does not hinder } \\
\text { decision-making while at the same time avoiding } \\
\text { disequilibrium and instability. }\end{array}$ & $\begin{array}{l}\text { - Jelenc (2008) } \\
\text { - Liedtka (1998) } \\
\text { - Liedtka and Rosenblum (1998) }\end{array}$ & $\begin{array}{l}\text { - Leadership } \\
\text { - Operations } \\
\text { - Mistakes } \\
\text { - Survival } \\
\text { - Employees } \\
\text { - Performance } \\
\text { - Political powers }\end{array}$ \\
\hline & System perspective & $\begin{array}{l}\text { This denotes the leadership's ability to adjust their } \\
\text { organisations to respond to environmental } \\
\text { challenges. }\end{array}$ & $\begin{array}{l}\text { - Bonn (2001) } \\
\text { - Liedtka (1998) }\end{array}$ & $\begin{array}{l}\text { - Environment } \\
\text { - Product } \\
\text { - Challenges } \\
\text { - Innovations } \\
\text { - Changes }\end{array}$ \\
\hline & Hypothesis-driven & $\begin{array}{l}\text { Hypothesis-driven focuses on generating and } \\
\text { testing hypothesis as its main activity. }\end{array}$ & $\begin{array}{l}\text { - Liedtka (1998) } \\
\text { - Liedtka and Rosenblum (1998) }\end{array}$ & $\begin{array}{l}\text { - Competition } \\
\text { - Optimism } \\
\text { - Leadership } \\
\text { - Technical process }\end{array}$ \\
\hline \multirow[t]{5}{*}{$\begin{array}{l}\text { Dependent variable: } \\
\text { Leadership } \\
\text { effectiveness }\end{array}$} & $\begin{array}{l}\text { Cross-cultural } \\
\text { competency }\end{array}$ & $\begin{array}{l}\text { The ability of leaders to work with and obtain } \\
\text { results from people from different cultures. }\end{array}$ & $\begin{array}{l}\text { - Green (2010) } \\
\text { - Yukl (2010) } \\
\text { - Johnson, Lenartowicz and Apud (2006) }\end{array}$ & $\begin{array}{l}\text { - Cultural problems } \\
\text { - Respect } \\
\text { - Ethnicity } \\
\text { - Equality } \\
\text { - Multicultural teams }\end{array}$ \\
\hline & Influence & This is leaders' ability to affect others. & $\begin{array}{l}\text { - Green (2010) } \\
\text { - Samson and Daft (2012) }\end{array}$ & $\begin{array}{l}\text { - Opportunistic } \\
\text { - Convincing } \\
\text { - Self-sacrifice } \\
\text { - Decisiveness } \\
\text { - Status quo }\end{array}$ \\
\hline & $\begin{array}{l}\text { Follower } \\
\text { commitment }\end{array}$ & $\begin{array}{l}\text { Denotes group members' commitment and } \\
\text { dedication to the group's goals and objectives. }\end{array}$ & - Yukl (2010) & $\begin{array}{l}\text { - Group success } \\
\text { - Feedback } \\
\text { - Support system } \\
\text { - Focus-driven } \\
\text { - Contribution }\end{array}$ \\
\hline & Versatility & $\begin{array}{l}\text { This is the leaders' ability to work with and obtain } \\
\text { results from others across the organisation. }\end{array}$ & $\begin{array}{l}\text { - Green (2010) } \\
\text { - Avolio and Bass (2004) }\end{array}$ & $\begin{array}{l}\text { - Multitasking } \\
\text { - Leadership } \\
\text { - Appropriate structures } \\
\text { - Expertise }\end{array}$ \\
\hline & Group organisation & $\begin{array}{l}\text { Leaders and members work together in an efficient } \\
\text { and effective way to attain positive productivity. }\end{array}$ & $\begin{array}{l}\text { - Green (2010) } \\
\text { - Epitropaki and Martin (2005) }\end{array}$ & $\begin{array}{l}\text { - Task-balancing } \\
\text { - Corrective action } \\
\text { - Understand group roles } \\
\text { - Performance review }\end{array}$ \\
\hline
\end{tabular}

Note: Please see the full reference list of the article, Muriithi, S.M., Louw, L. \& Radloff, S.E., 2018, 'The relationship between strategic thinking and leadership effectiveness in Kenyan indigenous banks', South African Journal of Economic and Management Sciences 21(1), a1741. https://doi.org/10.4102/sajems.v21i1.1741, for more information. 


\section{Empirical results}

\section{Sample description}

The descriptive statistics show that most respondents who participated in the study were women $(52.1 \%$ ) while $47.9 \%$ were men. The results further indicate that the majority of respondents were young bank employees aged between 25 and 40 years (63.8\%). Likewise, most respondents (54.4\%) were university graduates who had worked in the banking industry for a period ranging between 1 and 10 years (84\%) with more than half $(52.1 \%)$ having worked between 1 and 5 years. More than half of respondents (64.2\%) indicated that their banks had existed during the 1980s-1990s and had been exposed to the financial crisis period.

\section{Discriminant validity and reliability results}

Firstly, a CFA was conducted to determine unique factors in the data and assess the discriminant validity of the scales measuring the independent and dependent variables. The validity of the strategic thinking sub-variables (referred to as sub-constructs), namely strategic thinking (general), thinking in time, intent-focused, intelligent opportunism, system perspective and hypothesis-driven, were extracted and confirmed. In this study, only factor scores of 0.3 or above were accepted for further analysis (Hair et al. 2006:128).

From the results of CFA, only four of the six factors loaded successfully for strategic thinking. Two sub-constructs, thinking in time and system perspective, failed to load as expected and were eliminated from further analyses. Likewise, the thinking in time sub-construct did not load on any factor and was eliminated from further analysis. The system perspective sub-construct, on the other hand, loaded successfully on two items. In this study, a factor must have loaded on three or more measuring items to be accepted; the system perspective sub-construct was thus dropped from further analysis. The final results showed that only the strategic thinking (general), intent-focused, intelligent opportunism and hypothesisdriven sub-constructs loaded successfully and were therefore considered for further analysis. The final four sub-constructs and their factor loading values are shown in Table 4 . The factor structure that emerged from the CFA explained $47.6 \%$ of the variance in the data. All sub-constructs have eigenvalues of more than 1 indicating an acceptable level of significance (Farrington 2009:388-389; Hair et al. 2006:103).

The CA for the strategic thinking construct was calculated in order to determine the reliability of the scales of the measuring instrument. The CA score of 0.930 for strategic thinking was considered very reliable compared to the acceptable minimum score of 0.600 (Hair et al. 2007). The specific CA scores for each of the strategic thinking sub-constructs were strategic thinking (general) (0.791), intent-focused (0.821), intelligent opportunism (0.731) and hypothesis-driven (0.833). These findings are in agreement with similar studies and are therefore acceptable (Jelenc 2008).

Upon subjecting the leadership effectiveness construct to a CFA assessment, three sub-constructs (influence, follower commitment and versatility) loaded accordingly while two (group organisation and cross-cultural competency) did not load as expected and were consequently eliminated from further analysis. The leadership effectiveness construct explained $48.6 \%$ of the variance in the data. The results of the three subconstructs that successfully loaded as expected are presented in Table 5.

The CA score of 0.914 for the dependent variable, leadership effectiveness, was also considered very reliable. The CA scores for the sub-constructs were: influence (0.759), follower commitment (0.752) and versatility (0.738). The results indicated that items used to measure leadership effectiveness were reliable since all the scores, as previously justified, were greater than the 0.600 minimum acceptable score. The results are in agreement with similar studies (Green 2010; NCRVE 1994).

\section{Revised hypotheses}

Having conducted CFA tests and CA coefficients, the hypothesised framework and related sub-hypotheses required revision. It is notable that both the independent

TABLE 4: Results for factor analysis for strategic thinking.

\begin{tabular}{|c|c|c|c|c|}
\hline Items & $\begin{array}{c}\text { Factor 1: } \\
\text { Intent-focused } \\
\text { (Foc) }\end{array}$ & $\begin{array}{l}\text { Factor 2: } \\
\text { Hypothesis- } \\
\text { driven (Hyp) }\end{array}$ & $\begin{array}{c}\text { Factor 3: } \\
\text { Intelligence } \\
\text { opportunism (Opp) }\end{array}$ & $\begin{array}{c}\text { Factor 4: } \\
\text { Strategic thinking - } \\
\text { General (Gen) }\end{array}$ \\
\hline Gen5 & - & - & - & 0.747 \\
\hline Gen4 & - & - & - & 0.651 \\
\hline Gen6 & - & - & - & 0.527 \\
\hline Gen3 & - & - & - & 0.523 \\
\hline Foc3 & 0.730 & - & - & - \\
\hline Foc2 & 0.695 & - & - & - \\
\hline Foc4 & 0.631 & - & - & - \\
\hline Foc5 & 0.630 & - & - & - \\
\hline Foc1 & 0.584 & - & - & - \\
\hline Foc5 & 0.544 & - & - & - \\
\hline Opp4 & - & - & 0.719 & - \\
\hline Opp2 & - & - & 0.683 & - \\
\hline Орр3 & - & - & 0.650 & - \\
\hline Opp5 & - & - & 0.357 & - \\
\hline Hyp1 & - & 0.758 & - & - \\
\hline Hyp5 & - & 0.676 & - & - \\
\hline Hyp6 & - & 0.664 & - & - \\
\hline Hyp4 & - & 0.642 & - & - \\
\hline Нyp3 & - & 0.619 & - & - \\
\hline Нур2 & - & 0.608 & - & - \\
\hline
\end{tabular}

TABLE 5: Results of factor analysis for leadership effectiveness.

\begin{tabular}{lccc}
\hline Item & $\begin{array}{c}\text { Factor 1: Influence } \\
\text { (Inf) }\end{array}$ & $\begin{array}{c}\text { Factor 2: Follower } \\
\text { commitment (Fol) }\end{array}$ & $\begin{array}{c}\text { Factor 3: Versatility } \\
\text { (Ver) }\end{array}$ \\
\hline Inf2 & 0.680 & - & - \\
Inf3 & 0.665 & - & - \\
Inf5 & 0.553 & - & - \\
Inf4 & 0.536 & - & - \\
Inf1 & 0.432 & 0.616 & - \\
Fol1 & - & 0.472 & - \\
Fol2 & - & 0.425 & - \\
Fol3 & - & - & 0.655 \\
Ver4 & - & - & 0.641 \\
Ver2 & - & - & 0.609 \\
Ver1 & - & - & 0.458 \\
Ver3 & - & - & - \\
\hline
\end{tabular}


and dependent sub-constructs were revised, since some subconstructs were eliminated for failure to load as expected, as explained in the previous section. The revised hypotheses are listed below.

\section{Main hypothesis}

$\mathbf{H}^{1}$ : There is a positive relationship between strategic thinking and leadership effectiveness

\section{Sub-hypotheses $\mathrm{H}^{1.1}$}

$\mathbf{H}^{1.1}$ : There is a relationship between strategic thinking (construct) and its sub-constructs:

$$
\begin{aligned}
& \mathbf{H}^{1.1 a} \text { : Strategic thinking (general) } \\
& \mathbf{H}^{1.16} \text { : Intent-focused } \\
& \mathbf{H}^{1.1 \mathrm{c}} \text { : Intelligent opportunism } \\
& \mathbf{H}^{1.1 \mathrm{~d}} \text { : Hypothesis-driven }
\end{aligned}
$$

\section{Sub-hypotheses $\mathrm{H}^{1.2}$}

$\mathbf{H}^{1.2}$ : There is a relationship between leadership effectiveness (construct) and its sub-constructs:

$$
\begin{aligned}
& \mathbf{H}^{1.2 a} \text { : Influence } \\
& \mathbf{H}^{1.2 b} \text { : Follower commitment } \\
& \mathbf{H}^{1.2 c} \text { : Versatility }
\end{aligned}
$$

\section{Results of structural equation modelling}

As highlighted previously, both the CFA tests and CA coefficients confirmed that four of the strategic thinking sub-constructs and three of the leadership effectiveness subconstructs were appropriate for further analysis. As a result of the elimination of sub-constructs, the original proposed theoretical framework (referred to as a model from here onwards) was revised as shown in Figure 2.

The revised model and subsequent hypotheses were further tested using SEM in order to determine the level of goodness-of-fit. To this effect, the validation and testing of the hypothesis and sub-hypotheses was done using SEM.

\section{Results of the relationships between strategic

\begin{tabular}{|c|c|}
\hline Independent variable & Dependent variable \\
\hline $\begin{array}{l}\text { Strategic thinking } \mathrm{H}^{1.1 a-d} \\
\mathrm{H}^{1.1 a} \text { : Strategic thinking (general) } \\
\mathrm{H}^{1.11} \text { : Intent-focused } \\
\mathrm{H}^{1.1 c} \text { : Intelligent opportunism } \\
\mathrm{H}^{1.1 d} \text { : Hypothesis driven }\end{array}$ & $\begin{array}{l}\text { Leadership effectiveness } \mathrm{H}^{1.2 a-c} \\
\mathrm{H}^{1.2 a} \text { : Influence } \\
\mathrm{H}^{1.2 b} \text { : Follower commitment } \\
\mathrm{H}^{1.2 c} \text { : Versatility }\end{array}$ \\
\hline
\end{tabular} thinking and its sub-constructs}

The hypothesised relationships between strategic thinking and its sub-constructs are shown in sub-hypotheses $\mathrm{H}^{1.1 \mathrm{a}-\mathrm{d}}$ (Figure 2). Owing to space constraints, the structural relationship model of the study has not been included in this article. Instead, the structural and measurement

FIGURE 2: The revised hypothesised model of the relationship between strategic thinking competency and leadership effectiveness. model for strategic thinking and its sub-constructs is shown in Table 6.

\section{Goodness-of-fit results}

To measure the fitness of the actual or observed input correlation or covariance in relation to the prediction assumed by a theoretical model, a goodness-of-fit test is required (Hair et al. 1998:610-620; Venter 2003:257). In the current study, the goodness-of-fit was determined using four measures, namely normed Chi-square (the ratio of Chisquare to degrees of freedom: $\mathrm{X} / \mathrm{df}$ ), the root mean square error of approximation (RMSEA), The goodness-of-fit index (GFI) and comparative fit index (CFI). The results of goodness-of-fit tests for the structural strategic thinking model are presented in Table 7.

The results of various tests shown in Table 7 indicate the construct strategic thinking competency as fitting. The CMIN/ DF value of 3.157 falls between 2.0 and 5.0, indicating a good fit between the data and the model strategic thinking competency (Hooper, Coughlan \& Mullen 2008; Tabachnick \& Fidel 2007) The RMSEA value of 0.092 , on the other hand, was outside the acceptable range of $0.05-0.08$ and was therefore considered a poor fit (MacCullum, Browne \& Sugawara 1996). The GFI value of 0.838 was less than 0.90 thereby indicating a weak relationship. However, according to $\mathrm{Hu}$ and Bentler (1999) a value of 0.838 is still within an acceptable fit. Finally, the CFI value of 0.819 was within what is considered a good-fitting model as it was greater than 0.80 (Hooper et al. 2008). The results of the analysis of goodness-of-fit showed that CMIN/DF, GFI and CFI were acceptable to good fits, thus confirming that the strategic thinking competency model was acceptable. This also agreed with the minimum number of tests required for a test to be accepted in this study (Jaccard \& Wan 1996). The goodnessof-fit results mean that the four sub-constructs, namely strategic thinking (general), intent-focused, intelligent opportunism and hypothesis-driven are acceptable as fitting.

TABLE 6: Definition of structural and measurement model for strategic thinking and its sub-constructs.

Structural sub-model

\begin{tabular}{ll}
\hline Construct & Sub-constructs \\
\hline Strategic thinking & $\begin{array}{l}\text { Strategic thinking general, Intent-focused, } \\
\text { Intelligent opportunism, Hypothesis-driven }\end{array}$ \\
$\begin{array}{l}\text { Measurement model } \\
\text { Sub-constructs }\end{array}$ & Measured or observed measuring items \\
Strategic thinking general (Gen) & Gen3, Gen4, Gen5, Gen6 \\
Intent-focused (Foc) & Foc2, Foc3, Foc4, Foc5, Foc6, Foc7 \\
Intelligent opportunism (Opp) & Opp2, Opp3, Opp4, Opp5 \\
Hypothesis-driven (Hyp) & Hyp1, Hyp2, Hyp3, Hyp4, Hyp5, Hyp6 \\
\hline
\end{tabular}

TABLE 7: Goodness-of-fit indices for the structural strategic thinking model. Goodness-of-fit measure Values

Sample size 257

Normed Chi-square ( $\mathrm{X}^{2} /$ degree of freedom) (CMID/DF) 3.157 The root mean square error of approximation (RMSEA) 0.092 Goodness-of-fit index (GFI) $\quad 0.838$ $\begin{array}{ll}\text { Comparative fit index (CFI) } & 0.819\end{array}$ 
TABLE 8: Structural model parameter estimates and $p$-values for strategic thinking

\begin{tabular}{lcccc}
\hline $\begin{array}{l}\text { Sub-construct relationship with } \\
\text { strategic thinking competency (ST) }\end{array}$ & Estimates & $\begin{array}{c}\text { Standard } \\
\text { error }\end{array}$ & $\begin{array}{c}\text { Critical } \\
\text { ratio }\end{array}$ & $\boldsymbol{p}$ \\
\hline ST <---- Strategic thinking (general) & 0.497 & 0.064 & 7.725 & $<0.001$ \\
ST <---- Intent-focused & 0.486 & 0.057 & 8.542 & $<0.001$ \\
ST <---- Intelligent opportunism & -0.271 & 0.051 & -5.333 & $<0.001$ \\
ST <---- Hypothesis-driven & 0.402 & 0.055 & 7.344 & $<0.001$ \\
\hline
\end{tabular}

\section{Structural model parameter estimates and $p$-values for strategic thinking}

Similarly, the hypothesised relationship between strategic thinking competency and its sub-constructs was analysed. The results demonstrating the parameter estimates and the $p$-values are summarised in Table 8 .

As shown in Table 8, a significant positive relationship $(p<0.001)$ exists between strategic thinking competency and three of its sub-constructs; strategic thinking (general) (estimate $=0.497$ $p<0.001$ ), followed by intent-focused (estimate $=0.486$; $p<0.001$ ) and hypothesis-driven (estimate $=0.402 ; p<0.001$ ). There was, however, a negative relationship with intelligent opportunism (estimate $=-0.271 ; p<0.001$ ). Overall, the results indicate that these are important components of the strategic thinking competency. The findings provide support for $\mathrm{H}^{11.1 \mathrm{a}-\mathrm{d}}$.

The results show that the participating bank leaders had a general strategic view of their organisations, had intentfocused and hypothesis-driven leadership, and practised intelligent opportunism. The validation of strategic thinking sub-constructs is in line with similar studies that singled out lack of strategic thinking competency in organisations as a major source of leadership ineffectiveness (Bonn 2001; Jelenc 2008; Liedtka 1998; Rosche 2003). The negative relationship indicates that while intelligence opportunism was important in ensuring continuity and strategic focus, leaders must be aware of and be sensitive to changes that might negatively affect their efforts, thereby undermining their intended objectives or goals (Jelenc 2008).

\section{Results of the relationships between leadership effectiveness and its sub-constructs}

The hypothesised relationships between leadership effectiveness and its sub-constructs are shown in sub-hypotheses $\mathrm{H}^{1.1 a-c}$ (Figure 2). Owing to space constraints the structural relationship model has not been included in this article. Instead, the structural and measurement model for strategic thinking and its sub-constructs is shown in Table 9.

\section{Goodness-of-fit results}

In relation to goodness-of-fit indices, the analyses of the submodel leadership effectiveness and its constructs showed a good fit between the proposed measurement and structural sub-model, therefore signifying acceptable approximation of the data (see Table 10).

As shown in Table 10 the CMIN/DF value of 2.671 signifies a good fit between data and the sub-model, while the RMSEA
TABLE 9: Definition of structural and measurement model for leadership effectiveness and its constructs.

\begin{tabular}{llll}
\hline Model & Construct & Sub-constructs & $\begin{array}{l}\text { Measured or observed } \\
\text { measuring items }\end{array}$ \\
\hline Structural & $\begin{array}{l}\text { Leadership } \\
\text { effectiveness }\end{array}$ & $\begin{array}{l}\text { Influence, Follower } \\
\text { commitment, Versatility }\end{array}$ & - \\
Measurement & - & Influence (Inf) & Inf1, Inf2, Inf3, Inf4, Inf5 \\
& - & Follower commitment (Fol) & Fol1, Fol2. Fol3 \\
& - & Versatility (Ver) & Ver1, Ver2, Ver3, Ver5 \\
\hline
\end{tabular}

TABLE 10: Goodness-of-fit indices for the structural model on leadership effectiveness and its constructs.

\begin{tabular}{lc}
\hline Goodness-of-fit measure & Values \\
\hline Sample size & 257 \\
Normed Chi-square (X²/degree of freedom) (CMIN/DF) & 2.671 \\
Root mean square error of approximation (RMSEA) & 0.081 \\
Goodness-of-fit index (GFI) & 0.924 \\
Comparative fit index (CFI) & 0.921 \\
\hline
\end{tabular}

TABLE 11: Structural model parameter estimates and $p$-values for leadership effectiveness and its constructs.

\begin{tabular}{lcccc}
\hline $\begin{array}{l}\text { Sub-construct relationship with } \\
\text { leadership effectiveness (Leadeff) }\end{array}$ & Estimates & $\begin{array}{c}\text { Standard } \\
\text { error }\end{array}$ & $\begin{array}{c}\text { Critical } \\
\text { ratio }\end{array}$ & $p$ \\
\hline Leadeff <---- Influence & 0.717 & 0.056 & 12.747 & $<0.001$ \\
Leadeff <---- Follower commitment & 0.664 & 0.056 & 11.850 & $<0.001$ \\
Leadeff <---- Versatility & 0.483 & 0.058 & 8.372 & $<0.001$ \\
\hline
\end{tabular}

value of 0.081 slightly exceeds the accepted fit of between 0.61 and 0.08 (Grimm \& Yarnold 2000). The GFI value of 0.924 is seen as a good fit, as it ranged between 0.90 and 0.95 accepted level (Ghazali et al. 2013). Finally, the CFI value was 0.921 which is seen as very good (Hair et al. 2006) and well-fitting (Hooper et al. 2008; Hu \& Bentler 1999).

The findings indicate that three of the tests (CMIN/DF, GFI and CFI) were acceptable to good fits, therefore confirming an acceptable goodness-of-fit in the leadership effectiveness model. The goodness-of-fit results mean that the three sub-constructs, namely influence, follower commitment and versatility are accepted as fitting.

\section{Structural model parameter estimates and $p$-values for leadership effectiveness}

The hypothesised relationship between the leadership effectiveness construct and its sub-constructs (influence, follower commitment and versatility) was confirmed by use of SEM. The results shown in Table 11 demonstrate the parameters and the $p$-values of the data.

The results from Table 11 show that a positive relationship $(p<0.001)$ exists between the leadership effectiveness construct and its sub-constructs. The findings therefore provide support for sub-hypotheses $\mathrm{H}^{1.2 a-c}$. In terms of importance, the influence sub-construct has the greatest impact as a measure of leadership effectiveness (estimate $=0.717 ; p<0.001$ ), followed by follower commitment (estimate $=0.664 ; p<0.001$ ) and versatility sub-constructs (estimate $=0.483 ; p<0.001$ ) respectively. From the results, it can be asserted that the more bank leaders exercise their influence, ensure follower commitment and versatility, the more effective they are in their operations. 
TABLE 12: Structural model parameter estimates and $p$-values for strategic thinking competency and leadership effectiveness.

\begin{tabular}{lcccc}
\hline $\begin{array}{l}\text { Sub-construct relationship with } \\
\text { strategic thinking (Strat_T) }\end{array}$ & Estimates & $\begin{array}{c}\text { Standard } \\
\text { error }\end{array}$ & $\begin{array}{c}\text { Critical } \\
\text { ratio }\end{array}$ & $p$ \\
\hline Strat_T <---- Strat_think & 0.544 & 0.040 & 13.452 & $<0.001$ \\
Inf <---- Lead_compet & 0.612 & 0.051 & 12.052 & $<0.001$ \\
Fol <---- Lead_compet & 1.000 & - & - & - \\
Ver <---- Lead_compet & 0.660 & 0.660 & 9.963 & $<0.001$ \\
\hline
\end{tabular}

Inf, influence; Fol, follower commitment; Ver, versatility.

\section{The relationship between strategic thinking and leadership effectiveness}

To achieve the main purpose of this study, the relationship between the strategic thinking and leadership effectiveness constructs was examined as shown in the main hypothesis:

$\mathbf{H}^{1}$ : There is a positive relationship between strategic thinking competency and leadership effectiveness.

From the findings derived from SEM analysis and the parameters and the $p$-values represented in Table 12, there exists a strong positive relationship between strategic thinking and leadership effectiveness constructs.

Table 12 shows a positive relationship $(p<0.001)$ between the strategic thinking construct and the leadership effectiveness construct (estimate $=0.544 ; p<0.001$ ). The results provide support for Hypothesis $\mathrm{H}^{1}$. This relationship is corroborated by literature which indicates the need for bank leadership to pay attention to strategic thinking competency (Avolio \& Bass 2004; Howell \& Hall-Marenda 1999; Samson \& Daft 2012).

\section{Summary of empirical findings and conclusions}

The results of this study indicate that there exists a positive relationship between strategic thinking competency and leadership effectiveness among the indigenous banks in Kenya. This means that bank leadership must possess the right strategic thinking competencies in order to make their banks effective and achieve the desired performance. However, to achieve the level of effectiveness desired, the right strategic competencies must first be identified and implemented. In this study it was hypothesised that six strategic thinking (independent variable) sub-constructs were critical to leadership effectiveness as derived from various empirical studies and literature, namely strategic thinking (general), thinking in time, intent-focused, intelligent opportunism, system perspective and hypothesis-driven. Similarly, leadership effectiveness (dependent variable) was assumed to be influenced by five sub-constructs (crosscultural competency; influence; follower commitment; versatility and group organisation). Upon conducting several analyses and model tests ranging from CFA and CA to CFIs, the findings revealed significant adjustments to the proposed sub-constructs.

Strategic thinking competency: From the CFA performed on strategic thinking sub-constructs, four sub-constructs loaded successfully, namely strategic thinking (general), intent-focused, intelligent opportunism and hypothesis-driven. However, two sub-constructs (thinking in time and system perspectives) failed to load accordingly and were eliminated from further analyses. The four sub-constructs that loaded successfully were subjected to a CA test with positive results. A hypothetical test to establish the relationship between strategic thinking competency (see Figure 2) and its subconstructs indicated the existence of a relationship. These findings provide support for all strategic thinking subhypotheses $\left(\mathrm{H}^{1.1 \mathrm{a}-\mathrm{d}}\right)$. In order of importance, strategic thinking (general) is the most important constituent of strategic thinking competency, followed by intent-focused, hypothesis-driven and intelligent opportunism respectively. The result implies that the bank leaders need to pay attention to the four subconstructs of strategic thinking as being critical to these leaders' effectiveness and overall bank performance. The indigenous banking sector's leadership also needs to possess strategic thinking (general), intent-focused, intelligent opportunism and hypothesis-driven sub-competencies if leadership is to achieve the objectives of their banking and sustain successful performance levels.

Leadership effectiveness: From the CFA performed on leadership effectiveness sub-constructs, three sub-constructs loaded successfully, influence, follower commitment and versatility. However, two sub-constructs (cross-cultural competency and group organisation) failed to load as expected, leading to their elimination. Further tests of the hypothetical relationship indicated that a strong relationship exists between leadership effectiveness and its sub-constructs. Influence was found to be the most important sub-construct, followed by follower commitment and versatility respectively, thereby supporting $\mathrm{H}^{1.2 a-c}$. The results imply that influence, follower commitment and versatility sub-constructs are essential measures of leadership effectiveness within the indigenous banking sector in Kenya. The implications of the findings are that bank leaders should use industry-specific measures rather than rely on general leadership measures which are discussed in literature.

The hypothetical relationship between strategic thinking and leadership effectiveness $\left(\mathrm{H}^{1}\right)$ was tested. The results indicate a positive relationship $(p<0.001)$ between the two (estimate $=$ 0.544; $p<0.001)$. This relationship is in agreement with various studies, all emphasising the need for the banking industry to pay specific attention to strategic thinking competency as a key ingredient in leadership effectiveness and overall banking performance. This means than bank leaders must strive to maintain strategic thinking competency as a prerequisite for their effectiveness. This will enable them to synthesise information and be creative in their leadership.

\section{Managerial implications, limitations and recommendations for further research}

As indicated previously, four sub-constructs (general strategic thinking, intent-focused, intelligent opportunism and 
hypothesis-driven) were significant measures of the strategic thinking competency in this study. This finding has added significant value to a field of strategic thinking which is considered to be under-researched (Fairholm \& Fairholm 2009; Jelenc 2008). The few studies in strategic thinking have also not generated acceptable competencies or subconstructs essential for leaders. For instance, Liedtka's (1998) study had five sub-constructs while Jelenc (2008) had six sub-constructs. However, the four sub-constructs arising from this study are in agreement with Liedtka (1998), who cautioned against developing concepts that may not be relevant to practising managers. These findings are relevant to the indigenous banks' leadership that focuses on the four sub-constructs as being critical to their performance. The implication of these findings is that by paying attention to the four sub-strategic thinking competencies, bank leaders will be in a position to remain competitive and attain the desired strategic goal and leadership in their industry.

In relation to leadership effectiveness, this study has established three attributes (measures) essential for bank leadership to be considered effective. It is notable that the measures arising from this study have support from scholars (Erkutlu 2006; Green 2010; Yukl 2010) indicating their relevancy and the need for bank leadership to pay attention to them as determinants of their effectiveness. The implication is that leaders need to understand that they have influence over their employees which must be carefully exercised. They also need to clearly understand the role of follower commitment. It is only when followers are committed to a common cause that the banks can realise their set goals. Likewise, understanding of versatility will enable them to work with and obtain results from others, which is a major determinant of effectiveness. To achieve effectiveness, bank leaders must pay attention to empowering themselves and their employees with appropriate knowledge and skills.

Scholars have noted that although strategic thinking competency is important, it remains a critical research area owing to a lack of supporting theory and empirical literature regarding its role in leadership effectiveness, thereby making this study a major contribution to the body of knowledge (Liedtka \& Rosenblum 1998; Rosche 2003). However, since this is the first study on strategic thinking within the banking industry in Kenya, it is recommended that the banks devote time and resources to equip employees with appropriate skills in order to enhance their strategic thinking competency. While this study concentrated on strategic thinking competency and its relationship with leadership effectiveness, there are other competencies that may also influence leadership effectiveness, such as emotional intelligence, business acumen, personality, team-building, relationship-building and transformational leadership. It would be important to conduct further studies on these additional competences in order to determine their relevancy to strategic thinking and leadership effectiveness and overall bank effectiveness.

\section{Acknowledgements}

The authors would like to acknowledge various institutions involved either at data collection level, or with funding of the research and permission to conduct research. Among them are Rhodes University, Daystar University, National Commission for Science, Technology and Innovation (NACOSTI) and bank respondents who took part in this study.

\section{Competing interests}

The authors declare that they have no financial or personal relationships that may have inappropriately influenced them in writing this article.

\section{Authors' contributions}

S.M.M. was the principal investigator responsible for the fieldwork and data collection and co-writing of this article. L.L. was the supervisor, academic leader, designer, editor and and co-writer of this article. S.E.R. was responsible for all the statistical analysis of data, presentation and interpretation, testing research instruments and models. The three authors worked as a team in preparing this article.

\section{References}

Al-Zoubi, M.R., 2012, 'Leadership competencies and competitive advantage: Empirical study on Jordan telecommunications', European Journal of Business and Management 4(7), 234-247.

Ambutsi, P.B., 2005, 'A survey of corporate governance practices in selected commercial banks in Kenya', MBA thesis, Faculty of Post Graduate Studies, Daystar University, Nairobi.

Amos, T., 2012, 'Strategic leadership', in L. Louw \& P. Venter (eds.), Strategic management: Developing sustainability in Southern Africa, 2nd edn., pp. 439476, Oxford University Press, Cape Town.

Arnold, J., Cooper, C. \& Robertson, I., 1998, Work psychology. Understanding human behaviour in the workplace, 3rd edn., Pearson Education, Harlow, England.

Avolio, B.J. \& Bass, B.M., 2004, Multifactor leadership questionnaire: Third edition manual and sampler set, Mind Garden, Redwood City, CA.

Barnes, R., 2013, Do you know your CEO? The eight essential leadership skills, viewed 23 August 2013, from http://www.marketingmagazine.co.uk/article/1174126/ know-ceo-eight-essential-leadership-skills

Bass, B., 1990, Bass \& Stogdill's handbook of leadership: Theory research and managerial applications, 3rd edn., Free Press, New York.

Bonn, I., 2001, 'Developing strategic thinking as a core competency', Management Decision 39(1), 63-71. https://doi.org/10.1108/EUM0000000005408

Brunnermerier, M. K., 2009, 'Deciphering the liquidity and credit crunch 2007-2008', Journal of Economic Perspectives 23(1), 77-100. https://doi.org/10.1257/ jep.23.1.77

Burns, J.M., 1978, Leadership, Harper Row, New York.

Central Bank of Kenya, 2010, Kenya monthly economic review, Central Bank of Kenya (CBK), Nairobi, viewed 20 March 2010, from http://www.ouhk.edu.hk/PAU/ AlumniLink/AlumniTalk/040828/speech_marvincheung.pdf.

Chilcoat, R., 1995, Strategic art: The new discipline for the 21st century, US War College, Carlisle, PA.

Cooper, J., Fenimore, J. \& Nirenberg, J., 2012, 'Leadership effectiveness', in Encyclopedia of leadership, Sage, Thousand Oaks, CA, viewed 11 February 2011, from http://www.sagepub.com/northouse6e/study/materials/reference/ reference6.4.pdf

Epitropaki, O. \& Martin, R., 2005, 'From ideal to real: A longitudinal study of the role of implicit leadership theories on leader-member exchanges and employee outcomes', Journal of Applied Psychology 90(4), 659-676. https://doi. org/10.1037/0021-9010.90.4.659

Erkutlu, H., 2006, 'The impact of transformational leadership on organisational and leadership effectiveness: The Turkish case', The Journal of Management Development 27(7), 708-726,

EY, 2015, Global banking outlook 2015, Transforming banking for the next generation, EYGM Limited, New York. 
Fairholm, M. \& Fairholm, G., 2009, 'Leadership amid the constraints of trust', Leadership and Organization Development Journal 21(2), 102-109. https://doi. Leadership and Organization Deve
org/10.1108/01437730010318192

Fairholm, M.R., 2009, 'Leadership and organisational strategy', The Innovation Journal: The Public Sector Innovation Journal 14(1), 1-18.

Farrington, S.M., 2009, 'Sibling partnerships in South African small and medium-sized family businesses', MBA thesis, Faculty of management, Nelson Mandela Metropolitan University, Port Elizabeth.

Ghazali, R., Ahmad, A., Uli, J., Suandi, T. \& Hassan, S.A., 2013, 'Manager commitment to change: Commitment to change among managers in a selected service organization in Malaysia', in J.H. Westover (ed.), Leadership and organisational change, pp. 300-316, Common Ground Publication LLC, Champaign, IL.

Goldman, E.F., 2007, 'Strategic thinking at the top', MIT Sloan Management Review 48(4), 75-80.

Goldman, E.F., 2012, 'Leadership practices that encourage strategic thinking', Journa of Strategic Management 5(1), 25-40. https://doi.org/10.1108/17554251211 200437

Goleman, D., 1998, Working with emotional intelligence, Bantam Books, New York.

Grant Thornton, 2013, 2013 Banking outlook: Surviving and thriving in the new normal world of banking regulations, Grant Thornton LLP, Chicago, IL.

Green, j.m., 2010, 'Factors affecting perceptions of leadership effectiveness in an international organization: A study of middle management in Finnish MNC', PhD dissertation, Aston University, Birmingham, United Kingdom.

Grimm, L.G. \& Yarnold, P.R., 2000, Reading and understanding multivariate statistics, American Psychological Association, Washington, DC.

Hair, J.F., Anderson, R.E., Tatham, R.L. \& Black, W.C., 1998, Multivariate data analysis, 5th edn., Prentice Hall, Englewood Cliffs, NJ.

Hair, J.F., Black, W.C., Babin, B.J., Anderson, R.E. \& Tatham, R.L., 2006, Multivariate data analysis, 6th edn., Pearson Prentice Hall, Upper Saddle River, NJ.

Hair, J.F., Money A.H., Samouel, P. \& Page, M., 2007, Research methods for business, Wiley, West Sussex.

Haycock, K., Cheadle, A. \& Bluestone, K.S., 2012, 'Strategic thinking', Library Leadership \& Management 26(93/4), 1-23.

Hogan, J., Hogan, R. \& Kaiser, R.B., 2009, 'Management derailment: Personality assessment and mitigation', in S. Zedeck (ed.), American Psychological Association handbook of industrial and organizational psychology, pp. 1-51, American Psychological Association, Washington, DC.

Hooper, D., Coughlan, J. \& Mullen, M.R., 2008, 'Structural equation modeling: Guidelines for determining model fit', The Electronic Journal of Business Research Methods 6, 53-60, viewed 20 August 2010, from http://www.ejbrm.com

Howell, J. \& Hall-Marenda, K., 1999, 'The ties that bind: The impact of leader-member exchange, transformational and transitional leadership, and distance on predicting follower performance', Journal of Applied Psychology 84(5), 680-694.

Hu, L.-t. \& Bentler, P.M., 1999, 'Cutoff criteria for fit indexes in covariance structure analysis: Conventional criteria versus new alternatives', Structural Equation Modeling 6(1), 1-55. https://doi.org/10.1080/10705519909540118

Jaccard, J. \& Wan, C.K., 1996, LISREL approaches to interaction effects in multiple regression, Sage, Thousand Oaks, CA

Jelenc, L., 2008, 'The impact of strategic management schools and strategic thinking on the performance of Croatian entrepreneurship practice', PhD dissertation, Faculty of Economics, University of Ljubljana, Slovenia.

Johnson, J., Lenartowicz, T. \& Apud, S., 2006, 'Cross-cultural competence in international business: Toward a definition and model', Journal of International Business Studies 37, 525-543. https://doi.org/10.1057/palgrave.jibs.8400205

Kubicek, J., 2011, Leadership is dead: How influence is reviving it, Howard Books, New York.

Liedtka, J.M., 1998, 'Strategic thinking: Can it be taught', Long Range Planning 31(1), 120-129. https://doi.org/10.1016/S0024-6301(97)00098-8
Liedtka, J.M. \& Rosenblum, J.W., 1998, 'Shaping conversations: Making strategy, management change', California Management Review 39(1), 141-157. https:// doi.org/10.2307/41165880

MacCullum, R.C., Browne, M.W. \& Sugawara, H.M., 1996, 'Power analysis and determination of sample size for covariance structure modelling', in E. Venter, 2003, 'The succession process of small and medium-sized family businesses in South Africa', PhD thesis, University of Port Elizabeth, Port Elizabeth.

Markides, C., 2012, 'Thinking again: Fine-tuning your strategic thinking', Business Strategy Review 23(4), 80-85. https://doi.org/10.1111/j.1467-8616.2012. 00910.x

Mintzberg, H., 1994, The rise and fall of strategic planning, The Free Press, New York.

Mlachila, M., Park, S.G. \& Yaraba, M., 2013, Banking in sub-Saharan Africa: The macroeconomic context, in European Investment Bank, 2013, Banking in subSaharan Africa: Challenges and opportunities, pp. 7-27, European Investment Bank, Luxembourg.

Mwangi, J., 2012, Investors briefing, Equity Bank, Nairobi.

National Centre for Research in Vocation Education (NCRVE), 1994, Leadership effectiveness index manual, National Center for Research in Vocational Education, Macomb, IL.

Njuguna, N., 2013, The importance of the banking sector in the Kenyan economy, Remarks by Prof Njuguna Ndung'u, Governor of the Central Bank of Kenya, Bank of India, Kenya Branch, Diamond Jubilee Celebrations, Nairobi, 12 April 2013.

Norma, G.S., 1997, The role of leadership in business process reengineering: An empirical study of the relationship between leadership behaviour and the reengineering outcome, University of California, Los Angeles, CA.

O'Shannassy, T., 2006, 'Making sense of the strategic thinking literature to help build a new model of this mysterious construct', in Australian and New Zealand Academy of Management Annual Conference, Australian and New Zealand Academy of Management, Lindfield, NSW.

Personnel Decisions International Corporation, 2001, Management/supervisory competencies, Inter-American Development Bank, Washington, DC.

Raimond, P., 1996, 'Two styles of foresight: Are we predicting the future or inventing it?', Long Range Planning 29(2), 208-214. https://doi.org/10.1016/00246301(96)00010-6

Rosche, A.L.H.W., 2003, Personality correlates of strategic thinking in an organizational context, Faculty of the California School of Organizational Studies, Alliant International University, Alhambra, CA.

Samson, D. \& Daft, R.L., 2012, Management: Asia Pacific edition, Cengage Learning, Hampshire, UK.

Schoonover, S., 2011, 'Holistic leadership: A systems approach to leveraging personal and organisational capabilities', viewed from http://www.schoonover.com/ userfiles/Holistic\%20Leadership\%Framework.pdf

Sokpor, C.K.D., 2006, 'The role of central bank of Kenya in controlling bank failures: An investigative study', MBA thesis, Faculty of Postgraduate Studies, Daystar University, Nairobi.

Stogdill, R.M., 1974, Handbook of leadership, Free Express, New York.

Tabachnick, B.G. \& Fidell, L.S., 2007, Using multivariate statistics, 3rd edn., HarperCollins College Publishers, New York.

Torset, C., 2001, Strategic thinking: Why, what and how. An organizational model of strategic thinking, ECOS XIIV Colloqullum, Lyon.

Van Ballekom, p., 2013, Banking in sub-Saharan Africa: Challenges and opportunities, European Investment Bank, Luxembourg.

Venter, E., 2003, 'The succession process of small and medium-sized family businesses in South Africa', PhD thesis, University of Port Elizabeth, Port Elizabeth.

Yukl, G., 2010, Leadership in organizations, 7th edn., Pearson Education Inc, Upper Saddle River, NJ.

Yukl, G.A., 1994, Leadership in organizations, 3rd edn., Prentice-Hall, Englewood Cliffs, NJ. 